\title{
Risk Factors and Pathways to Imprisonment among Incarcerated Women in Victoria, 1860-1920
}

\author{
Alana Piper, University of Technology Sydney, New South Wales, Australia \\ Email: a.piper@griffith.edu.au \\ Victoria M Nagy, Deakin University, Melbourne, Victoria, Australia
}

\begin{abstract}
Criminological studies have found that men's and women's pathways to imprisonment differ, with risk factors such as substance abuse, mental illness, socioeconomic circumstances and past victimisation more strongly associated with female prisoners. However, limited quantitative or longitudinal research exists on how the risk factors associated with female offending may have shifted over time. This article investigates the criminal careers and pathways to imprisonment of 6,042 women incarcerated in Victoria between 1860 and 1920, and the risk factors associated with subsequent recidivism. The findings suggest that, while many of today's risk factors were present historically, there have been notable shifts across time.
\end{abstract}

\section{Keywords}

female offenders; criminal careers; recidivism; historical criminology; gender

The late nineteenth and early twentieth century saw significant legal and social developments in Australia likely to impact female criminal activity: population growth and mobility; a period of economic expansion and collapse; intensive policing of prostitution through public order offences; growing interventionism in matters relating to the care of children; and the establishment of a range of institutions to deal with the poor, criminal and mentally ill. While various scholars have examined the effect of these structural factors on the policing and punishment of women, limited quantitative work has been done on how these forces found expression in the risk factors experienced by women as individuals when it came to their likelihood of offending. ${ }^{1}$

\footnotetext{
${ }^{1}$ For discussion of the concept of risk factors as it applies in criminology, see: Joseph Murray, David P. Farrington, and Manuel P. Eisner, "Drawing Conclusions about Causes from Systematic Reviews of
} 
This article examines individual risk factors associated with female imprisonment in this crucial period through analysis of the backgrounds and criminal careers of 6,042 women imprisoned in Victoria between 1860 and 1920. As such, it represents the first longitudinal study of the criminal careers of late nineteenth and early twentieth-century female offenders in Australia, and one of the largest longitudinal studies of historical female offenders to date. The collected data enables exploration of the life courses of women offenders and illuminates links between recidivism and socioeconomic, educational, occupational, migration, family and age profiles, as well as substance abuse and psychological histories. Our findings suggest that many personal risk factors common to female offending are shared across historical and contemporary contexts.

Internationally, criminologists have tracked women's criminal careers alongside men's to identify risk factors to criminal involvement, typically concluding that men and women experience different gendered pathways to imprisonment. ${ }^{2}$ Similar research has been undertaken in Australia as well. ${ }^{3}$ While most research on the question of gendered pathways is qualitative, quantitative research also supports a gendered pathways argument. Results indicate that there are three main pathways for women's incarceration: childhood victimisation leading to mental illness and substance abuse; a relational pathway from a dysfunctional adult relationship whereby a woman has her

Risk Factors: The Cambridge Quality Checklists," Journal of Experimental Criminology 5, no. 1 (2009): 1-23; David P. Farrington, Hannah Gaffney, and Maria M. Ttofi, "Systematic Reviews of Explanatory Risk Factors for Violence, Offending and Delinquency," Aggression and Violent Behaviour 33 (2017): 24-36.

2 Katharina J. Joosen et al., "How 'Gendered' Are Gendered Pathways into Prison?: A Latent Class Analysis of the Life Experiences of Male and Female Prisoners in the Netherlands," Journal of Developmental and Life-Course Criminology 2, no. 3 (2016): 321-40; Carolyn Rebecca Block et al., "Long-Term Patterns of Offending in Women," Feminist Criminology 5, no. 1 (2010): 73-107; Kristi Hoi Singer, "Feminist Perspectives on Female Offending," Women \& Criminal Justice 12, no. 1 (2000): 23-51.

${ }^{3}$ Sally S. Simpson, Jennifer L. Yahner, and Laura Dugan, "Understanding Women's Pathways to Jail: Analysing the Lives of Incarcerated Women," Australian \& New Zealand Journal of Criminology 41 (2008): 84-108; Patricia Easteal, "Women in Australian Prisons: The Cycle of Abuse and Dysfunctional Environments," The Prison Journal 81, no. 1 (2001): 87-112. 
self-efficacy reduced, leading to substance abuse and/or mental illness; and a socioeconomic pathway through which the broader challenges women face in society (e.g. lack of financial and educational supports) can result in unemployment and financial stressors leading to criminal activity. ${ }^{4}$ In Victoria, women's recidivism has recently been linked to drug and alcohol misuse, poor socioeconomic status (along with low levels of educational attainment) and mental health issues. ${ }^{5}$ Particular social groups, such as adolescents and women of colour, carry particular risk, especially when coupled with the factors above. ${ }^{6}$ To what extent did such risk factors apply to historical offending by women?

An examination of this question can only proceed with detailed data on the backgrounds and offending patterns of women, preferably over their life course. It is only in recent years that a small body of life-course studies by historical criminologists and criminal justice historians has emerged, encouraged by the increasing digitisation of historical records. ${ }^{7}$ Particularly groundbreaking has been the work by Barry Godfrey, David Cox and Stephen Farrall examining a group of persistent offenders from Crewe, England, between 1880 and 1940, which showed that while some important factors in contemporary desistance, such as stable employment, exerted an effect on historical offenders, others, such as marriage, did not. ${ }^{8}$ However, their study consisted predominantly of male offenders; historical scholarship on female offenders' criminal

\footnotetext{
${ }^{4}$ Emily J. Salisbury and Patricia Van Voorhis, "Gendered Pathways: A Quantitative Investigation of Women Probationers' Paths to Incarceration,' Criminal Justice \& Behavior 36, no. 6 (2009): 541-66.

${ }^{5}$ Victorian Ombudsman, Investigation into the Rehabilitation and Reintegration of Prisoners in Victoria, 2015, 94-96.

${ }^{6}$ Sally S. Simpson et al., "Age-Graded Pathways into Crime: Evidence from a Multi-Site Retrospective Study of Incarcerated Women," Journal of Developmental and Life-Course Criminology 2, no. 3 (2016): 296-320; Don Weatherburn, Arresting Incarceration: Pathways out of Indigenous Imprisonment (Canberra: Aboriginal Studies Press, 2014), 74-87.

${ }^{7}$ Helen Johnston et al., "Reconstructing Prison Lives: Criminal Lives in the Digital Age," Prison Service Journal 210 (2013): 4-9.

${ }^{8}$ Barry S. Godfrey, David J. Cox, and Stephen D. Farrall, Criminal Lives: Family Life, Employment, and Offending (Oxford: Oxford University Press, 2007), 75-79.
} 
careers remains limited to a few works from England and the Netherlands. ${ }^{9}$ These tend to emphasise economic marginalisation and disconnection from family relationships as determining factors in female pathways to imprisonment. This article finds that most contemporary risk factors to women's offending — with the possible exceptions of age and race-were historically significant to women's imprisonment, with socioeconomic context and substance abuse being issues of particular importance.

\section{Method}

The dataset used in this analysis is drawn from the Central Register of Female Prisoners, a series of records created by Victoria's penal department to register names, personal details and convictions of incarcerated women. ${ }^{10}$ Upon a woman's first entry to prison, a record was created for her that would be updated on subsequent returns.

Prison administrators appear to have been generally successful when it came to associating female prisoners with past crimes, often noting that a woman had been convicted under a different name to that first listed on their page in the register. Some women accumulated a string of different identities, with one prisoner having fourteen aliases listed.

The format of the recordkeeping system remained consistent across several decades. Basic biographical details such as birthplace, year of birth, religion, occupation and literacy were entered on a woman's first entry into the prison system.

\footnotetext{
${ }^{9}$ Helen Johnston, Barry Godfrey, and Jo Turner, “'I Am Afraid She Is Perfectly Responsible for Her Actions and Is Simply Wicked': Reconstructing the Criminal Career of Julia Hyland," in Law, Crime and Deviance since 1700: Micro-Studies in the History of Crime, ed. Anne-Marie Kilday and David Nash (London: Bloomsbury, 2017), 209-26; Marian Weevers and Catrien Bijleveld, "Mad, Bad, or Sad? Dutch Female Beggars and Vagabonds Sent from the State Labor Institution to the State Mental Asylum at the Turn of the 19th Century," Women \& Criminal Justice 21, no. 6 (2014): 176-92; Marian H. A. C. Weevers, Margo De Koster, and Catrien C. J. H. Bijleveld, "Swept up from the Streets or Nowhere Else to Go? The Journeys of Dutch Female Beggars and Vagrants to the Oegstgeest State Labor Institution in the Late Nineteenth Century," Journal of Social History 46, no. 2 (2012): 416-29. ${ }^{10}$ Central Register of Female Prisoners, VPRS 516/P0, Public Records Office Victoria (hereafter PROV).
} 
Details of the convictions that had resulted in a woman's incarceration, including date of conviction, offence, where and by whom they were tried, and the sentence, were also recorded, with subsequent convictions and returns to prison added to the same page. There were also sections where officials could add notes about the woman's previous history. Comments made in this section routinely included whether a woman was married, their year of arrival to Victoria if a migrant, and details of minor convictions that had been punished by fines or short periods in police lockups, rather than prison terms. Sometimes officials also recorded information about an offender's family, such as who was caring for their children during their gaol term. Finally, there was a section devoted to the woman's time in prison, detailing entries and exits, disciplinary infractions committed and punishment administered, and transfers to other institutions, such as charity homes or lunatic asylums.

Between 2014 and 2015, a spreadsheet of the names, registration numbers and basic biographical details for all the women listed in the central register was created as part of the digitisation efforts of the Public Records Office Victoria. Subsequently, the authors, with help from a research assistant, oversaw the transcription of additional information contained in the prison records into an SPSS database. This provides a sample of 6,042 individual women who first entered the central prison system between 1860 and 1920. It does not include women incarcerated in Victoria's prisons during this period who had first been imprisoned prior to 1860 , as their records exist in earlier registers. The listing of convictions that had not resulted in imprisonment meant that three women in the sample had convictions prior to 1860 , the earliest date for a woman's first known conviction being 20 September 1854. Furthermore, 124 women continued offending after 1920, the latest date for a woman's last known conviction being 23 December 1947. 
The richness of the register information makes it an invaluable source for understanding women's offending in the context of their life course, although it is hampered by the nature of the information collection practices. Information concerning occupation, marital status and other biographical details was taken from women on their first imprisonment, and was seldom updated, although it is likely that details changed over women's life course. Likewise, officials often relied on the women's own statements for their information, which in some cases was either deliberately or unintentionally misleading, particularly on matters such as age or occupation. Concerning a prisoner's conviction histories, however, prison staff relied on both official police records and the prisoner's own statements. Staff would sometimes note disagreement between these sources in the register; interestingly, this was often in the context of a prisoner admitting convictions that were not listed on their police record. Occasionally, the nature of the charges listed in prison registers also varies from that related in other sources, although this usually represents a minor variation or simplification.

Additionally, authorities did not always enter information in a consistent format for convictions that had not resulted in imprisonment. Typically, they entered the date of conviction, offence type, location of trial and sentence, but sometimes they only entered the date of conviction and sentence. As the convictions did not result in imprisonment, they would have involved minor offences. This is confirmed by occasional brief notations by officials that all the convictions on the dates listed were for offences such as drunkenness or disorderly conduct. Some records, though, only give a total number of previous convictions prior to first imprisonment without any details of offence, sentence or date of conviction, suggesting such convictions had not been verified against other official records. For the purposes of this analysis, we have 
opted for the more conservative approach of only using convictions with dates attached, meaning that the overall level of recidivism is likely to be underestimated. Information was also missing from the register for some records; where possible, data for these women was supplemented by recourse to the Victoria Police Gazettes, or occasionally by newspaper reports sourced from the National Library Trove database.

This article examines the risk factors associated with female offending by offering an overview of the offending patterns present in the sample, and analysing how these correlate to different socioeconomic contexts, ethnic and migration backgrounds, family histories, age structures, evidence of substance abuse, and psychological issues. Chi-square analyses are used to evaluate the significance of particular factors against their association with different levels of recidivism; this is then examined against the years that women first entered prison and the birth cohorts to which they belonged. This allows analysis of how strong the association of particular risk factors with female offending remained over the sample's time period, as well as how this compares to contemporary findings. Qualitative evidence and case studies from the dataset are also drawn upon to illustrate particular trends.

\section{Offending Patterns}

Historical studies both in Australia and abroad have found that, during the late nineteenth and early twentieth century, most women were imprisoned as a result of minor public order convictions. ${ }^{11}$ Almost sixty per cent of the women in the sample

\footnotetext{
${ }^{11}$ Judith A. Allen, Sex \& Secrets: Crimes Involving Australian Women Since 1880 (Melbourne: Oxford University Press, 1990), 20-26; Leigh S. L. Straw, Drunks, Pests and Harlots: Criminal Women in Perth and Fremantle, 1900-1939 (Kilkerran: Humming Earth, 2013), 9; L. Mara Dodge, "Whores and Thieves of the Worst Kind": A Study of Women, Crime, and Prisons, 1835-2000 (DeKalb: Northern Illinois University Press, 2002), 111; Lucia Zedner, "Women, Crime, and Penal Responses: A Historical Account," Crime and Justice 14 (1991): 307-62; Lucy Williams, Wayward Women: Female Offending in Victorian England (Pen \& Sword: South Yorkshire, 2016), 117.
} 
first entered the prison system on charges of vagrancy, disorderly conduct or public drunkenness, compared to just twenty per cent first imprisoned for theft offences, and less than ten per cent imprisoned for violent crimes (see table 1). The figures do not change much when examining the entirety of women's offending histories: while 73.9 per cent of prisoners amassed public order convictions at some point, only 28.8 per cent of women acquired theft convictions and just 12.9 per cent violent convictions. The petty nature of most female offending is also reflected in the court levels at which women were tried. The majority—5,064 women or eighty-four per cent—were only ever convicted at summary court level. In contrast, just ten per cent were convicted at the higher courts, while six per cent were convicted at both summary and higher court levels. Consequently, 93.1 per cent of female prisoners never received a sentence longer than twelve months.

\section{$<$ Insert table 1 here $>$}

The widespread use of these short custodial sentences for petty offences created a situation wherein high numbers of women cycled in and out of prison. ${ }^{12}$ Singleconviction offenders comprised only 42.7 per cent of the sample, meaning the majority of women were recidivists but most at low-level rates, with 37.4 per cent accumulating two to five convictions. Those in the midlevel (six to nine convictions) or chronic recidivist range (ten or more convictions) comprised approximately ten per cent of prisoners each (see table 2). The highest number of convictions amassed by a female prisoner was $188 .{ }^{13}$ The proportion of women convicted of theft or violent offences rose with each increasing level of recidivism, but it was still public order offending that predominated in recidivists' criminal careers (if the conviction histories of women

\footnotetext{
${ }^{12}$ Mark Finnane, Punishment in Australian Society (Melbourne: Oxford University Press, 1997), 88.

${ }^{13}$ Elizabeth Turnbull, prisoner no. 7125, vol. 13, VPRS 516/P0, PROV.
} 
whose offences overwhelmingly consisted of poverty or alcohol abuse may be termed as such). ${ }^{14}$ Although recidivism was common, the bulk of women (72.2 per cent) only offended across a short duration of less than three years. Increased levels of recidivism were unsurprisingly associated with longer periods of offending. The longest record was fifty-two years between the first and last convictions. ${ }^{15}$

\section{$<$ Insert table 2 here $>$}

Due to the declining overall levels of imprisonment from the 1880 s onwards, a disproportionate number of women-3,180 - first entered the prison system in the 1860s and 1870s. In contrast, only 724 women first entered the system between 1900 and 1920. However, as levels of female imprisonment fell, the level of recidivism was rising (see figure 1). Whereas the mean number of convictions accumulated by a woman who entered the prison system in the 1860 s was 2.6 , this rose progressively so that those first incarcerated in the 1910s would acquire a mean of 7.6 convictions in the course of their criminal careers. There are thus two important trends to consider when assessing how different risk factors may have interacted with women's offending over time: the decreasing number of women being imprisoned by the twentieth century and the greater levels of chronicity evinced by those women.

\section{$<$ Insert figure 1 here $>$}

\section{Socioeconomic Context}

Technology, education, the labour economy and social attitudes towards women underwent remarkable transformations between the lifetime of the first-born offender, in 1777 , and the last-born offender, in 1902. The disproportionate number of women

\footnotetext{
${ }^{14}$ For a more in-depth discussion of the mix of crime types women exhibited over their criminal careers, see our forthcoming article: "Versatile Offending: Criminal Careers of Female Prisoners in Australia, 1860-1920," Journal of Interdisciplinary History 48, no. 2 (2017).

${ }^{15}$ Ellen Green, prisoner no. 581, vol. 2, prisoner no. 1322, vol. 9 and prisoner no. 6833, vol. 12, VPRS 516/P0, PROV.
} 
entering the prison system during the 1860 s and 1870 s meant that over half the women in the sample were born before the 1850s; however, it was the women born between the 1860 s and 1880 s who were the most repeatedly imprisoned (see figure 2). The influx of migrants during the mining boom of the 1850s, as well as lingering concerns about a remnant Vandemonian convict populace, ${ }^{16}$ meant Victoria was particularly exercised on the issue of crime control at the start of the sample study period. ${ }^{17}$ The high rate of female imprisonment during this period is testament to the considerable powers wielded by police in the regulation of public space-police were deployed in particular to crack down on the visibility (rather than existence per se) of prostitution or other "immoral" behaviour. ${ }^{18}$ It was not just women from criminal subcultures that were subject to such policing practices, but women of the "lower" orders more generally, as traditional working-class pastimes and use of public space became criminalised, often in gendered ways. ${ }^{19}$

The colony experienced a severe economic depression during the early 1890 s, just as many of the women who went on to become chronic recidivists were in their formative adolescent or early adult years. As Susanne Davies chronicles, during the depression many women resorted to begging or prostitution to support their families, leading to their over-representation in vagrancy prosecutions. ${ }^{20}$ The hardship of these years may have had long-lasting effects on some women's lives, leading them onto a

\footnotetext{
${ }^{16}$ Stefan Petrow, "Convict-Phobia': Combating Vandiemonian Convicts in 1850s and 1860s Victoria," Journal of Australian Colonial History 14 (2012): 260-71.

${ }^{17}$ Graeme Davison and David Dunstan, “"This Moral Pandemonium' Images of Low Life," in The Outcasts of Melbourne: Essays in Social History, ed. Graeme Davison, David Dunstan, and Chris McConville (Sydney: Allen \& Unwin, 1985), 29-57.

${ }^{18}$ Dean Wilson, The Beat: Policing a Victorian City (Melbourne: Circa, 2006), 185; Chris McConville, “The Location of Melbourne's Prostitutes, 1870-1920," Australian Historical Studies 19, no. 74 (1980): 86-97.

${ }^{19}$ Lynette Finch, The Classing Gaze: Sexuality, Class and Surveillance (St Leonards: Allen \& Unwin, 1993), 43-44; Sue Davies, "Working Their Way to Respectability: Women, Vagrancy and Reform in Late Nineteenth Century Melbourne," Lilith: A Feminist History Journal 6 (1989): 50-63.

${ }^{20}$ Susanne Elizabeth Davies, "Vagrancy and the Victorians: The Social Construction of the Vagrant in Melbourne 1880-1907” (PhD thesis, University of Melbourne, 1990), 361-63.
} 
pathway of continued offending even once the economy had stabilised. At a societal level, the depression also had long-lasting effects by changing understandings of what poverty meant, which as Davies observes, led not only to an increase in social welfare provisions but also to limitations in the ease with which police could institute vagrancy charges. ${ }^{21}$ These socio-legal changes influenced the declining numbers of female prisoners during the early twentieth century.

\section{$<$ Insert figure 2 here $>$}

During the late nineteenth and early twentieth century, poverty was thus not only a major risk factor for female offending but was also, itself, effectively the "crime" for which women were most often imprisoned. One-third of women first entered prison on charges of vagrancy, begging or lacking lawful means of support (see table 1); onehalf of all female prisoners would amass such charges over the course of their criminal careers, with a significant positive association between poverty-related convictions and increasing levels of recidivism (see table 2). Contemporary studies suggest that, for women, economic deprivation is heavily associated with other factors - such as participation in sex work-likely to lead to repeat offending. ${ }^{22}$ While only seven per cent of the sample had convictions directly related to prostitution, such as soliciting or residing in a brothel, this rose to 28.5 per cent among the chronic recidivists (see table 2). However, prostitution probably occurred among a much higher proportion of the sample, as policing of prostitution during this period predominantly occurred through the institution of vagrancy or other public order charges. ${ }^{23}$ Some women living on the

\footnotetext{
${ }^{21}$ Davies, "Vagrancy and the Victorians," 390-420.

${ }^{22}$ Lisa Pasko and Meda Chesney-Lind, "Running the Gauntlet: Understanding Commercial Sexual Exploitation and the Pathways Perspective to Female Offending," Journal of Developmental and LifeCourse Criminology 2, no. 3 (2016): 275-95; Peggy C. Giordano, Jill A. Deines, and Stephen A. Cernkovich, "In and out of Crime: A Life Course Perspective on Girls' Delinquency," in Gender and Crime: Patterns of Victimization and Offending, ed. Karen Heimer and Candace Krutschnitt (New York: New York University Press, 2006), 17-40.

${ }^{23}$ Raelene Frances, Selling Sex: A Hidden History of Prostitution (Sydney: University of New South Wales Press, 2007), 140.
} 
streets or through the precariousness of prostitution even welcomed the security that incarceration offered. ${ }^{24}$ The bulk of these women appear to have been inhabitants of "marvellous" Melbourne, with 70.4 per cent of female prisoners convicted by courts in the capital (see table 2).

Other socioeconomic indicators recorded by the prison registers also indicate female prisoners' marginalised status. Just over a third of the female prisoners in the sample were illiterate or had only limited literacy when they entered the system, with over ninety per cent of these women born prior to the 1860 s, thus missing out on the introduction of free and compulsory schooling under Victoria's 1872 Education Act. ${ }^{25}$ Literacy levels were not only an effect of the age profile though; while only ten per cent of Victoria's female population registered as illiterate during the 1861 census, less than half the women who entered the prison system during the 1860 s were able to read and write. Although the situation improved over time, during the 1890 s illiteracy was still over ten per cent among first-time female prisoners, yet under five per cent among the female population generally at the 1891 census. Surprisingly though, when controlling for birth cohort, there was no relationship between literacy and recidivism. The relationship between illiteracy and female offending may have acted more as a marker of other factors likely to lead to offending, such as poverty, rather than an actual barrier to moving from crime to gainful employment, given the menial nature of most female nineteenth-century occupations. ${ }^{26}$

Despite growing industrialisation, domestic service remained the largest employer of women, accounting for at least two-thirds of prisoners in the sample (see

\footnotetext{
${ }^{24}$ Alana Piper, “'I go out worse every time': Connections and Corruption in a Female Prison,” History Australia 9, no. 3 (2012): 147.

25 Alan Barcan, A History of Australian Education (Melbourne: Oxford University Press, 1980), 131.

${ }^{26}$ Beverley Kingston, My Wife, My Daughter, and Poor Mary Ann: Women and Work in Australia (Melbourne: Thomas Nelson, 1975); Rae Frances, The Politics of Work: Gender and Labour in Victoria 1880-1939 (Cambridge; New York: Cambridge University Press, 1993).
} 
table 2). Most of the remainder were engaged in some other form of working-class occupation, such as factory or sewing work. Few women were recorded as unemployed but reported occupations should not be taken as indicators of stable employment. For instance, Beatrice Phillips was listed as a servant, but one wonders how often she was engaged in service between her first conviction at age eighteen in 1896 and her last, aged sixty-six in 1944, during which time she amassed 153 convictions, mostly for drunkenness but also for assault, property damage, larceny and soliciting prostitution. ${ }^{27}$ Perhaps the only significance that can be attached to the reported occupations of women in the sample is that they show that the vast bulk came from economically marginalised backgrounds, with just 5.1 per cent occupied in personal household duties and 2.2 per cent engaged in middle-class occupations, such as nursing, teaching or shopkeeping. (Women in the latter group were often situational offenders whose crimes were connected to their occupations, such as nurses performing abortions, ${ }^{28}$ or hotelkeepers stealing from customers. ${ }^{29}$ )

\section{Ethnicity and Migration Background}

Historically, as today, there was considerable interest in the relationship between criminality and ethnicity, with colonial authorities expressing trepidation in particular about the contributions of Irish-born women to crime rates. ${ }^{30}$ As the first-born woman in the sample was born a decade before the process of colonisation even began in Australia, it is unsurprising that 59.8 per cent of female prisoners were born outside the Australian colonies, mostly in Great Britain. Irish women were disproportionately

\footnotetext{
${ }^{27}$ Beatrice Phillips, prisoner no. 6656, vol. 12 and prisoner no. 7565, vol. 14, VPRS 516/P0, PROV.

28 Janet Wilmot, prisoner no. 6728, vol. 13, VPRS 516/P0, PROV.

${ }^{29}$ Jane Dunn, prisoner no. 6225, vol. 11, VPRS 516/P0, PROV.

${ }^{30}$ Pauline Hamilton, “'No Irish need apply': Prejudice as a Factor in the Development of Immigration Policy in New South Wales and Victoria, 1840-1870" (PhD thesis, University of New South Wales, 1979).
} 
imprisoned, comprising 18.9 per cent of the female population in the 1861 census, but 43.5 per cent of the female prisoners entering the system in the $1860 \mathrm{~s}$. This disparity did not disappear until the 1910s, a situation likely influenced by a range of contributing factors, from cultural dissonance leading to higher levels of policing and socioeconomic exclusion, through to Irish women having been conditioned to institutionalisation by previous experience in workhouses and orphanages. ${ }^{31}$

Whatever the risk factors were that meant Irish women were prone to incarceration though, it does not appear to have led to higher rates of persistent offending, with Irish women showing a normal distribution across different recidivism levels. There was also little evidence of an overall relationship between migration and recidivism: controlling for birth cohort, only female prisoners born in the 1850 s and 1890 s showed a statistically significant association between being born overseas and repeat offending. Although not statistically significant, there was a trend in the sample in which women who immigrated between the ages of eighteen and twenty-two showed higher levels of chronic recidivism to those who emigrated when they were either younger or older (see table 2). Such women were more likely to have emigrated without their families as part of immigration schemes to import young, single women as domestics ${ }^{32}$ and thus may have ended up more socially isolated in the absence of family networks and the opportunities open to other immigrants to form new social bonds through school and neighbourhood contacts.

\footnotetext{
${ }^{31}$ Trevor McClaughlin, “'I Was Nowhere Else': Casualties of Colonisation in Eastern Australia in the Second Half of the Nineteenth Century," in Irish Women in Colonial Australia, ed. Trevor McClaughlin (St Leonards: Allen \& Unwin, 1998), 142-62; Ciara Breathnach, "Even 'Wilder Workhouse Girls': The Problem of Institutionalisation among Irish Immigrants to New Zealand 1874," The Journal of Imperial and Commonwealth History 39, no. 5 (2011): 771-94.

32 Jan Gothard, Blue China: Single Female Migration to Colonial Australia (Melbourne: Melbourne University Press, 2001).
} 
Only four women who first entered the prison system between 1860 and 1920 were explicitly identified as Indigenous on their prison record. Others not so identified may have been of Aboriginal descent, but government statistics confirm that — unlike the historical male prison population and in contrast to current trendsVictorian gaols admitted very few Aboriginal women during this period. ${ }^{33}$ This was due to their diversion from the prison system into other systems of control that Indigenous women were already subject to during this period as "inmates" of missions and reserves. As Peggy Brock explains, this meant that "the criminal justice system was not called on to restrain or control Aboriginal behaviour; a parallel, segregated system fulfilled this task." ${ }^{\prime 34}$ It was only from the 1960 s that greater freedom of movement ironically led to high levels of police surveillance and incarceration of Aboriginal women, mostly for the same types of public order offences that historically led to high levels of female imprisonment in general. ${ }^{35}$

Two of the Indigenous prisoners in the sample were low-level recidivists from regional areas convicted for public order offences. The other two were chronic recidivists convicted mostly for vagrancy, drunkenness and prostitution offences, one in Melbourne, the other in Melbourne and regional courts. Another woman identified as African-American was also a chronic recidivist, convicted of eighteen offences in Melbourne between 1915 and 1944, including robbery, larceny, soliciting prostitution and multiple public order offences. ${ }^{36}$ While the sample is obviously too small to make any definitive statements, the experiences of these five women suggest that, while

\footnotetext{
${ }^{33}$ In 1860, for instance, government records of women simply taken into police custody reveal that, of 3,795 women arrested, only seven were Aboriginal. See "Statistical Register of Victoria, 1860 - Law, Crime," VPP, 1861, 24-25.

${ }^{34}$ Peggy Brock, "Protecting Colonial Interests: Aborigines and Criminal Justice," Journal of Australian Studies 21, no. 53 (1997): 124.

${ }^{35}$ Elizabeth Grant, "The Incarceration of Australian Aboriginal Women and Children," in Silent System: Forgotten Australians and the Institutionalisation of Women and Children, ed. Paul Ashton and Jacqueline Z. Wilson (North Melbourne: Australian Scholarly Publishing, 2014), 43-58.

${ }^{36}$ Alice Hunter, prisoner no. 7312, vol. 13, VPRS 516/P0, PROV.
} 
women of colour in this period were not prone to criminal involvement, once they were part of the criminal justice system they may have found it particularly difficult to escape it.

\section{Family Situation}

Several historical studies have suggested that a lack of family support played a significant role in women's likelihood of offending, with unusually high numbers of single and widowed women in British and European prisons during the eighteenth and nineteenth centuries. ${ }^{37}$ This has been associated with the high number of unmarried women left by the heavy male casualties from the various wars of this period, which may in turn have encouraged women to resort to crime in the absence of a male breadwinner. In the Australian colonies, however, a reversed gender imbalance encouraged high marriage rates among women and, as a result, some 56.3 per cent of the 2,328 prisoners whose marital status was recorded were married when they first entered the prison (see table 2). This marriage rate still appears slightly lower than that of the general female population. Whereas the 1861 census found that some 69.6 per cent of the adult female population of Victoria were married, this figure drops to approximately 63.1 per cent of women who first entered the prison system in the $1860 \mathrm{~s}$.

However, the designation of married obscures women separated from their husbands, a situation that anecdotal evidence suggests was common among female offenders. ${ }^{38}$ This lack of marital stability is occasionally alluded to in the comments

\footnotetext{
${ }^{37}$ Weevers and Bijleveld, "Mad, Bad or Sad?," 178; Olwen Hufton, "Women without Men: Widows and Spinsters in Britain and France in the Eighteenth Century," Journal of Family History 9, no. 4 (1984): 355-56.

${ }^{38}$ Alana Piper, “'I'll have no man': Female Families in Melbourne's Criminal Subcultures, 18601920," Journal of Australian Studies 39, no. 4 (2015): 444-60.
} 
section of women's records. A woman imprisoned for idle and disorderly behaviour in 1869 stated that she had not seen her husband "for some years"; ${ }^{39}$ another imprisoned that same year as a habitual drunkard was not sure but thought it was probable her husband was dead. ${ }^{40}$ Some had husbands whose work had taken them "up country" or to sea. Other remarks entered by officials point to wider disconnection from family relationships. Prison officers appear to have tried to determine the extent of the support system women possessed, reporting on the existence of parents, children and siblings, often along with their place of residence and occupations. Some women had been separated from their families by the tyrannies of distance; others simply had notations reading "no friends" or "no relatives living". Such note-taking perhaps suggests recognition that women left without the support of male partners or that other family members were potentially more likely to reoffend, given the economic as well as emotional stress such lack of interpersonal relationships might cause.

While the lack of systematic information gathering by officials inhibits quantitative analysis, the observations of women's records do provide some qualitative evidence suggesting that the types of family situations associated with female offending today were also prevalent historically. It is generally accepted in criminological literature that family dynamics_ - particularly disconnected, abusive or unstable family relationships and domestic partnerships — are highly correlated with female pathways to prison. ${ }^{41}$ A number of prisoners in the sample had children who had been committed to institutions, or themselves had been wards of the state. Sarah Copas, the prisoner who amassed the highest number of disciplinary infractions

\footnotetext{
39 Jane Smith, prisoner no. 1580, vol. 3, VPRS 516/P0, PROV.

${ }^{40}$ Eliza Grady, prisoner no. 1517, vol. 3, VPRS 516/P0, PROV.

${ }^{41}$ Easteal, "Women in Australian Prisons," 87-112.
} 
across her various prison stays, was noted to have spent time in an industrial school as a "neglected child". ${ }^{42}$ There were also instances of inter- or intra-generational offending where officers recorded that women had fathers, mothers, husbands or siblings who were also serving sentences. In several instances this was because inmates had co-offended with their relatives, such as the sisters (aged nine and eleven) imprisoned for stealing potatoes in 1860 (possibly at the instigation of their mother), ${ }^{43}$ or another woman whose family relations were the subject of the criminal investigation against her, leading to her and her father's conviction for incest with each other when she was twenty-three years old. ${ }^{44}$

Family violence was another issue that - while it may have been a common element of prisoners' experiences - is only glimpsed at in the prison records. When it does appear, it is usually in the guise of women as offenders, although for some this may have been a product of past or ongoing victimisation. Some female prisoners were convicted for violence against their children, either as their only offence or in the context of general offending. Jane Cavanagh's varied career of twenty-five convictions between 1862 and 1877 for offences such as vagrancy, larceny, damaging property and keeping a disorderly house included one for assaulting her child in 1867. ${ }^{45}$ Several women also served sentences for assaulting or threatening the life of their husbands, actions that (as today) may have been undertaken in self-defence against the men's violent tendencies. Janet Sager, for instance, was sentenced to six months' imprisonment in 1880 for using threatening language to her husband and being drunk and disorderly; she had several other minor convictions as well. ${ }^{46}$

\footnotetext{
${ }^{42}$ Sarah Copas, prisoner no. 1628, vol. 3, VPRS 516/P0, PROV.

${ }^{43}$ Mary Ann (Ellen) Bourke, prisoner no. 609, vol. 1 and Mary Ann Bourke, prisoner no. 610, vol. 1, VPRS 516/P0, PROV; "Police city court," Argus, 4 August 1860, 6.

44 Jessie Ellen Dove, prisoner no. 6915, vol. 13, VPRS 516/P0, PROV.

45 Jane Cavanagh, prisoner no. 904, vol. 2, VPRS 516/P0, PROV.

${ }^{46}$ Janet Sager, prisoner no. 4541, vol. 8, VPRS 516/P0, PROV.
} 
Newspaper reports, however, reveal that her husband, Peter, a convicted thief, ${ }^{47}$ had a history of assaulting her, even smashing a chair into her face the previous year. ${ }^{48}$ (In an example of the intergenerational transmission of violence, the Sagers' granddaughter, also called Janet, was a victim of both childhood sexual abuse and later spousal assault. ${ }^{49}$ ) Another prisoner included in the sample who later became a published poet, Janet Dibben, depicted domestic violence as a customary aspect of women's lives, declaring that marriage inevitably meant "Sometimes you will get a crack". ${ }^{50}$ Victimisation and poor family relations may thus have played a role in female offending and recidivism just as they do today.

\section{Age and Onset of Offending}

Contemporary research suggests that juvenile offenders of both genders commit an exceedingly high proportion of criminal acts, usually desisting by early adulthood, although women seem more likely than men to start offending later in life. ${ }^{51}$ It appears adult-onset offending was the norm among historical female offenders, with 56.1 per cent of women first entering the prison system aged thirty years or older, with a median age of thirty-two. This did include some offenders who were first convicted at a younger age but sentenced only to fines or short periods in police lockups. For instance, Annie Brennan was thirty-four when she first entered the prison system, but she already had fifteen previous convictions dating back to 1882 when she was convicted of an assault at the age of fifteen. ${ }^{52}$ Overall though, the data does not change much when examining age at first known conviction, with 53.7 per

\footnotetext{
${ }^{47}$ Peter Saeger, prisoner no. 15770, vol. 28, VPRS 515/P0, PROV.

48 "Town talk," Geelong Advertiser, 3 February 1879, 2.

49 "Police court," Geelong Advertiser, 22 March 1899, 4; Ballarat Star, 9 May 1923, 2.

50 Janet Dibben, “The Widow," Shearer's Song, Melbourne, n.d.

${ }^{51}$ Simpson et al., "Age-Graded Pathways into Crime," 296-320.

${ }^{52}$ Annie Brennan, prisoner no. 2233, vol. 4, VPRS 516/P0, PROV.
} 
cent aged at or above thirty years and a median age of thirty-one. (Of course, the sample does not capture youthful offenders sentenced to other institutions or penalties who desisted before an imprisonment sentence became a more likely outcome of their crimes.) In contrast to contemporary findings, a younger age at first offence was not associated with increased offending over the life course; those first entering the prison system aged under twenty accumulated the lowest mean number of convictions of all age groups, at 2.43 convictions, with the most convicted being those who entered the system in their twenties and thirties with a mean of 4.3 and 4.74 convictions respectively.

While approximately half the women in the sample were aged in their twenties or thirties when they entered the prison system, there were also outliers at both ends of the spectrum. There were 513 first-time prisoners aged under nineteen, most convicted in the early 1860 s before the introduction of industrial schools under the 1864 Neglected and Criminal Children's Act. A small number of girls convicted of vagrancy, the youngest being just three years old, were actually children of adult female prisoners sentenced for vagrancy to keep them with their mothers in the absence of alternative care. ${ }^{53}$ Mirroring contemporary trends, the very young and the elderly appear to have been at the greatest risk of poverty, with vagrancy convictions significantly associated with those aged under twenty or above fifty-nine. The lateonset offending by the 262 women first convicted when sixty years or older (the eldest first-time prisoner being ninety-six) was likely the result of the lack of welfare institutions or support for impoverished women no longer able to earn a living, or who had otherwise become nuisances to the community. The declining incarceration

\footnotetext{
${ }^{53}$ Shurlee Swain and Nell Musgrove, "Contained and Confined: Female Incarceration in NineteenthCentury Australia," in Silent System, 6.
} 
rate can be partly attributed to the increased provision of such institutions from the $1890 \mathrm{~s}$, and the introduction of the old age pension in $1900 .{ }^{54}$

\section{Alcohol and Drug Use}

While contemporary studies show substance abuse to be a risk factor for offending in both genders, it has been found to be particularly influential on female pathways to imprisonment. ${ }^{55}$ Historically, alcohol-related charges played a significant role in female imprisonment, with 16.1 per cent of the sample convicted of public drunkenness over the course of their criminal careers. Although public drunkenness was an offence intended to control disruptive behaviour, it was also one that could be deployed selectively against those perceived as "problem" groups by criminalising ordinary working-class drinking practices and street activity. While both men and women were historically arrested for public intoxication, gendered expectations meant female drunkenness was problematised in ways that male excess was not, encouraging more severe policing and punishment of female drinkers, as well as increased media scrutiny of them. ${ }^{56}$

The greater likelihood of incarceration and social ostracism attached to a drunkenness conviction for women, rather than actual substance abuse issues, may thus have acted as a pathway into continued offending; however, the repeated convictions of many women on drunkenness charges do suggest underlying addiction

\footnotetext{
${ }^{54}$ Davies, Vagrancy and the Victorians, 398-420.

${ }^{55}$ Holly Johnson, "Drugs and Crime: A Study of Incarcerated Female Offenders," Research and Public Policy Series 63 (Canberra: Australian Institute of Criminology, 2004); Felipe Estrada and Anders Nilsson, "Does It Cost More to Be a Female Offender? A Life-Course Study of Childhood Circumstances, Crime, Drug Abuse, and Living Conditions," Feminist Criminology 7, no. 3 (2012): 196-219.

${ }^{56}$ Alana Piper, “'A Growing Vice': The Truth About Brisbane Girls and Drunkenness in the Early Twentieth Century," Journal of Australian Studies 34, no. 4 (2010): 485-97; Leigh Straw, "“The Worst Female Character': Criminal Underclass Women in Perth and Fremantle, 1900-1939," Journal of Australian Studies 37, no. 2 (2013): 208-24.
} 
issues. Drunkenness convictions were associated with increased levels of recidivism (table 2), as well as a higher likelihood of convictions for violent, property and sex work offences: in comparison to the 16.1 per cent of female prisoners convicted of drunkenness overall, drunkenness convictions were held by 18.7 per cent of women convicted of larceny, by 23 per cent convicted of non-fatal assaults, and by 31.1 per cent convicted for prostitution offences. There was also a high correlation with the other public order offences for which women were most commonly imprisoned, such as disorderly behaviour (31.8 per cent) and obscene language (49.6 per cent).

Contemporaries were not unaware of the effect that criminalising public intoxication had on elevating female imprisonment statistics, with many turn-of-thecentury officials bemoaning the uselessness of repeatedly convicting the same women for drunkenness or other minor offences without dealing with the underlying problem of alcohol addiction. ${ }^{57}$ In 1890 , Victoria even passed the Inebriates Act in an attempt to divert dipsomaniacs from the prison system into treatment centres, but poor funding and administration meant these institutions never achieved their desired function, echoing the challenges that drug and alcohol abuse pose to crime policies today. ${ }^{58}$

There were only three identified drug offenders in the sample, indicating the limited role drugs played in offending prior to the mid-twentieth century. Two of the women-Jane Sprague and Nellie Smith—were convicted in connection with the nineteenth-century culture of opium-smoking. ${ }^{59}$ While little evidenced in the prison records, other sources from the period indicate that many women, particularly those

\footnotetext{
${ }^{57}$ Report of the Board Appointed To Inquire into the Question of the Treatment of Habitual Drunkards, VPP, 1899, 7, 23.

${ }^{58}$ Davies, Vagrancy and the Victorians, 421-430.

${ }^{59}$ Jane Sprague, prisoner no. 7262, vol. 13, VPRS 516/P0, PROV; Nellie Smith, prisoner no. 7038, vol. 13, VPRS 516/P0, PROV.
} 
who inhabited brothels in Melbourne's Chinese quarter, were opium users. ${ }^{60}$ Sprague and Smith differed though in that they were both accused of being involved in the smuggling of opium - trafficking it into Chinese camps at Ballarat and Rutherglen respectively. However, unlike most contemporary female drug offenders, neither Sprague's nor Smith's records suggested extensive criminal involvement, with Smith amassing only three further convictions for minor offences, and Sprague disappearing from the Victoria prison register after her solitary drug conviction. The record of the third woman had more in common with the modern drug offender. ${ }^{61}$ Myrtle McKenzie was convicted of possessing a dangerous drug, namely cocaine, in 1926, when use and distribution of the drug in Melbourne was growing rapidly. ${ }^{62}$ With twenty-seven convictions between 1918 and 1938 for offences such as soliciting prostitution and drunkenness, McKenzie likely had pre-existing connections to the criminal underworld that facilitated her introduction to the drug.

More emblematic of the role of substance abuse in female pathways to imprisonment are the records of the five women in the sample convicted of drinking methylated spirits, which was criminalised in Victoria under the 1928 Poisons Act. These five women each amassed between 49 and 153 convictions over criminal careers that ranged from seventeen to forty-eight years. Although most convictions were for public order offences, they also numbered multiple convictions for theft, violence and property damage between them. This suggests the correlation of substance use with serious and persistent offending; however, this cannot be simplistically read as evidence of cause and effect. As other studies have suggested, there is an overlap between substance abuse and other risk factors prevalent among

\footnotetext{
${ }^{60}$ Alfred W. McCoy, Drug Traffic: Narcotics and Organized Crime in Australia (Sydney: Harper \& Row, 1980), 42.

${ }^{61}$ Myrtle McKenzie, prisoner no. 7427, vol. 14, VPRS 516/P0, PROV.

${ }^{62}$ McCoy, Drug Traffic, 46.
} 
female offenders, such as poverty, histories of victimisation and mental health problems. ${ }^{63}$ The propensity for drunkenness among historical female offenders might thus alternatively be read as an attempt to self-medicate in response to other problems in their lives that already predisposed them to criminal involvement.

\section{Psychological and Behavioural Issues}

While it is difficult to accurately assess the extent of mental illness among historical prisoners, existing studies of Australian institutions have noted an obvious "porous relationship" between nineteenth-century prisons and lunatic asylums. ${ }^{64}$ This was especially true for women, who were not only perceived as more susceptible to insanity in general, but whose criminality was constructed as more deviant than men's and therefore more likely the result of mental aberrance. ${ }^{65}$ Approximately two per cent of female prisoners were recorded being transferred directly from prison to an asylum (see table 2); more would have been sent there on separate occasions not noted in the prison record. There was a significant positive association between an asylum transfer and recidivism, with 4.4 per cent of the chronic recidivists transferred to a mental health facility. Edith Turnbull, for example, amassed forty-one convictions from 1900 onwards before eventually being committed to the Yarra Bend Lunatic Asylum in 1920, an event that apparently terminated her criminal career. ${ }^{66}$ However, other offenders moved fluidly between institutions through a cycle of transfers, discharges and reoffending.

\footnotetext{
${ }^{63}$ Estrada and Nilsson, "Does It Cost More to Be a Female Offender?," 196-219.

${ }^{64}$ Swain and Musgrove, "Contained and Confined," 7.

${ }^{65}$ Cathy Coleborne, "Legislating Lunacy and the Female Lunatic Body in Nineteenth-Century

Victoria," in Sex, Power and Justice: Historical Perspectives on Law in Australia, ed. Diane Kirkby, (Oxford: Oxford University Press, 1995), 86-98.

${ }^{66}$ Edith Turnbull, prisoner no. 6734, vol. 12, VPRS 516/P0, PROV.
} 
Additional factors recorded in the prison registers may also indicate an association between mental illness and persistent offending. There was a moderately significant relationship between higher recidivism and being convicted of attempting suicide, although this may have been influenced by a reluctance of magistrates to imprison women for suicide attempts when their prior histories were otherwise respectable. It is moreover difficult to determine whether the psychological issues indicated by a suicide attempt fostered women's involvement in other criminal behaviour, or if such mental health problems were the product of other risk factors such as socioeconomic marginalisation, or even incarceration itself. While for some women a suicide attempt was the prelude to a string of minor convictions,${ }^{67}$ for others it followed upon repeated previous incarcerations. ${ }^{68}$

Similarly, it is unclear what meaning can be attached to the seventy-nine women convicted under Victoria's 1916 Venereal Diseases Act. There was again a significant positive relationship between recidivism and venereal disease, sufferers having a mean average of fourteen convictions compared to four among other women. The most prolific venereal disease sufferer was Elsie Williams, with 140 convictions between 1918 and 1947, predominantly for drunkenness, vagrancy, soliciting prostitution and unlawful possession of goods. ${ }^{69}$ The involvement of women such as Williams in prostitution was presumably what led to their infection with venereal disease; it remains possible though that such disease subsequently caused mental deterioration that influenced women's continued offending. Thus, while there are some suggestions of poor psychological health among historical female prisoners, it is

\footnotetext{
${ }^{67}$ Mary McMahon, prisoner no. 2329, vol. 4, VPRS 516/P0, PROV.

${ }^{68}$ Amy Cochrane, prisoner no. 4868, vol. 8, VPRS 516/P0, PROV.

${ }^{69}$ Elsie Williams, prisoner no. 7402, vol. 13, VPRS 516/P0, PROV.
} 
difficult to establish the sequencing of this in women's criminal careers, and thus whether it represents a risk factor, correlate or product of female offending.

\section{Conclusion}

Results from our analysis of Victoria's prison registers between 1860 and 1920 indicate that factors such as mental illness, substance abuse, familial networks, migration background, geographic mobility, urban location and economic deprivation were significantly associated with female imprisonment and recidivism. These historical factors mirror risk factors identified among female prisoners today. However, changes across time are also evident. While illiteracy was a risk factor for nineteenth-century female offending, this was likely an indication of overall economic deprivation and showed no particular association with recidivism, probably because it did not represent the same bar to participation in the labour force historically that it does today. For women offenders, Aboriginality is seemingly a much stronger risk factor for imprisonment today than it was during the colonisation period. Migration was historically significant, but only in terms of culture of origin, with Irish women overrepresented in the prison population. Adolescence was not the peak period of offending that it is typically found to be today. Meanwhile, drink seems to have held the role that drugs have assumed in contemporary criminal offending.

This analysis thus demonstrates the potential utility to criminologists of the quantitative data about crime increasingly being retrieved by digital history projects, particularly in relation to topics like female life-course offending where large contemporary datasets are often lacking. It also underscores the utility of criminological perspectives and methods to historical analysis. Determining how different risk factors have been influenced by the sociohistorical context, and the ones 
that have proven the most enduring across time, has obvious implications not just for academic research but for practitioners and policymakers. This initial foray into one particular dataset has identified various significant trends and avenues of inquiry; more concentrated research on these specific strands is now needed. 